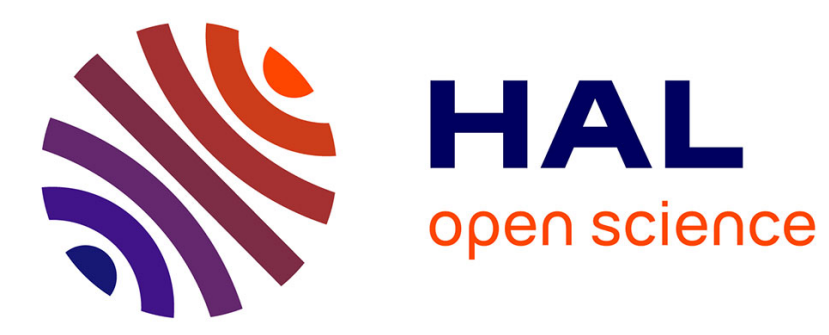

\title{
Does Education Really Matter for Environmental Quality?
}

\author{
Somlanaré Romuald Kinda
}

\section{To cite this version:}

Somlanaré Romuald Kinda. Does Education Really Matter for Environmental Quality?. 2011. halshs00552225

\section{HAL Id: halshs-00552225 \\ https://shs.hal.science/halshs-00552225}

Preprint submitted on 5 Jan 2011

HAL is a multi-disciplinary open access archive for the deposit and dissemination of scientific research documents, whether they are published or not. The documents may come from teaching and research institutions in France or abroad, or from public or private research centers.
L'archive ouverte pluridisciplinaire HAL, est destinée au dépôt et à la diffusion de documents scientifiques de niveau recherche, publiés ou non, émanant des établissements d'enseignement et de recherche français ou étrangers, des laboratoires publics ou privés. 


\section{Document de travail de la série}

Etudes et Documents

E 2010.28

\section{Does Education Really Matter for Environmental Quality?}

KINDA Somlanaré Romuald *

octobre 2010

* Ph-D student at CERDI, Université d'Auvergne, 65, bd F. Mitterrand, 63000 Clermont Ferrand - France. Email : kindaromi@yahoo.fr 


\title{
Does Education Really Matter for Environmental Quality?
}

\author{
KINDA Somlanaré Romuald ${ }^{1}$
}

\begin{abstract}
This paper investigates the impact of education on the growth of carbon dioxide emissions per capita over the period 1970-2004 in 85 countries. Using panel data and applying GMMSystem estimations, our results suggest that education has no impact on the growth of air pollution for the whole sample. Nonetheless, this effect is sensitive to the sampling of countries according to their level of development. Indeed, while the effect remains insignificant in the developing countries sub-sample, education does matter for air pollution growth in the developed countries. More interestingly, when controlling for the quality of political institutions, the positive effect of education on air pollution growth is mitigated in the developed countries while being insignificant in the developing countries.
\end{abstract}

Key words: Carbon dioxide per Capita (Q53); Education (I2); Democratic institutions (043)

I am grateful to Pascale Combes Motel for helpful comments and suggestions. I am also grateful to participants at the CERDI doctoral seminar, at International Energy Workshop (IEW 2010), at GLOBELICS Conference 2009.

${ }^{1} \mathrm{Ph}-\mathrm{D}$ student at CERDI, Université d'Auvergne; 65 Bd F Mitterand, 63000 Clermont Ferrand France. France. Email : kindaromi@yahoo.fr 


\section{Introduction}

In recent years, the debate on climate change has been renewed because environmental and socio-economic effects are now more evident. The debate on climate change is now one of the most popular public topics in both developed and developing countries. According to many scientists, global warming is caused by greenhouse gases that are essentially produced by the increase of carbon dioxide emissions.

Analyzing the determinants of environment quality shows that economic growth is an important factor. A vast body of economic literature verified the possible existence of the hypothesis of environmental kuznet's curve. According to the environmental kuznet's curve, environment quality is initially reduced with the rise of the income and development process. At a given level, income raises can then be associated with an improvement of the environment. Some economists like Grossman and Kruger (1995) and the World Bank Report (1992) justify this hypothesis by claiming that there would be a positive income elasticity of demand for environmental quality. In other words, the demand for a higher environmental quality increases with income.

Since the Rio summit (1992), education is also considered to be an essential tool for the protection of the environment and sustainable development. Educated people would be more conscious of environmental problems and therefore would have behaviors and lifestyles in favour of improving the environment. Considered a driving force behind economic growth, education also appears to be a way to of stimulating environmental protection.

This paper aims at highlighting the importance of education on environment quality over the period 1970-2004 in 85 developing and developed countries. We use panel data and apply modern GMM-System estimations. This rigorous approach takes into account the observed and unobserved heterogeneity of countries and solves the endogeneity problems of some variables. Our results suggest that education has no impact on the growth of air pollution for the whole sample. Nonetheless, this effect is sensitive to the sampling of countries according to their level of development. Indeed, while the effect remains insignificant in the developing countries sub-sample, education does matter for air pollution growth in the developed countries. More interestingly, when controlling for the quality of political institutions, the positive effect of education on air pollution growth is mitigated in the developed countries while being insignificant in the developing countries.

Low education level and the relative weakness of political institutions might explain the absence of effect of education in developing countries. The combination of these factors 
strongly reduces the capability of people to express their preferences for a better environment. Our results are robust and relevant by taking into account alternative education data.

The remainder of the paper is organized as follows. Section 2 shows how education could influence environment quality. Section 3 derives an estimating equation and shows results and the last section is devoted to the conclusion.

\section{How does education affect environment quality?}

From the literature on environmental economics, we group the papers into two different trends.The first approach concerns the civic externalities of education. Nelson and Phelps (1966) consider that education enhances one's ability to receive, decode, and understand information, and that information processing and interpretation have an impact on learning and change behaviours.

In recent years, education is considered a vehicle for sustainable development and thus for the fight against pollution. For Robitaille (1998), education is "a permanent learning process that contributes to the training of citizens whose goal is the acquisition of knowledge, soft skills, know-how and good manners. It enables them to get involved in individual and collective actions, based on the principles of interdependence and solidarity. This will help coordinate "person-societyenvironment" relationships and support the emergence of sustainable societies that are sociopolitically and economically fair, here and elsewhere, now and for future generations."

Farzin and Bond (2006) identify three channels for a positive relation between education level and the improvement of environmental quality.

Firstly, educated people would be more conscious of environmental problems and therefore would have behaviors and lifestyles in favour of environmental improvement. The lack of information and knowledge about the consequences of environmental damage may limit the consumers' willingness to pay. Then, educated people have access to information and change their behaviour. Bimonte (2002) shows that an increase in people's education is often accompanied by increases in their preferences favoring a higher level of environmental protection. For a given income, education increases the minimum level of environmental quality that a country requires.

Secondly, educated people have a higher capacity or ability to use existing means and channels in order to express their environmental preferences. They can also get organized in pression groups or lobbies, to obtain the implementation of environmental public policies. Dasgupta and Wheeler (1997) analyse factors encouraging people to complain about environmental damages in China. They show that Chinese provinces with relative low education have a lower marginal propensity to complain about environmental damages. 
Without education, people have little information about harmful risks, effects of the environmental damages in the long term and are only interested in the obvious impact. That could also be explained by the fact that less educated people have little confidence in their own capacity to influence authorities. Moreover Hettige et al.(1993) show that without effective government policies, communities with high education take favorable actions to control or reduce emissions of pollution.

Thirdly, Farzin and Bond (2006) consider that educated people are "more likely to generate an environmentally progressive civil service, and therefore have democratically-minded public policymakers and organizations that are more receptive to public demands for environmental quality".

Despite the relative consensus on the positive effect of education, other authors believe that education is a factor that increases pollution. Jorgenson (2003) finds that education has a positive effect on the ecological footprint. Educated people have more income and purchasing power and are encouraged to an overconsumption of material goods. Indeed, they desire to live well by accumulating material goods without caring about the consequences of this happiness and the ideological model of "consume more to be happier" (Princen et al. 2002) conveyed by advertising and the media leading to a greater consumption of material goods. Because overconsumption of goods is a factor of over-exploitation of natural resources, educated people contribute to environmental degradation (pollution of air, soil, and water). These empirical results show a positive and significant effect of enrollment on the ecological footprint per capita.

According to the second approach, the accumulation of education has a positive impact on labor productivity and income. According to the environmental kuznet's curve, environment quality is initially reduced with the rise of the income and development process. At a given level, income raises can then be associated with an improvement of the environment. That is explained by the fact that an increase of income generates the resources that are necessary for pollution abatement. The effect of education on the environment quality can be indirect through income.

Secondly, education facilitates the development and adoption of new technologies that are more productive in a closed economy (Bartel and Lichtenberg (1987)). According to Wells (1972), educated people adopt innovation sooner than less educated people. From the marketing literature, he shows that early (consumers) purchasers of new products are more educated. Nelson \& Phelps (1966) conclude that "a better educated farmer is quicker to adopt profitable new processes and products since for him, the expected payoff from innovation is 
likely to be greater and the risk likely to be smaller; for he is better able to discriminate between promising and unpromising ideas, and hence less likely to make mistakes. The less educated farmer, for whom the information in technical journals means less, is prudent to delay the introduction of a new technique..."

Education also stimulates the creation of knowledge; innovation is a result of these functions of research and dissemination from research centers and institutions and promotes new ideas and knowledge. These institutions can train many engineers and scientists and develop a research sector that is favorable to pollution abatement. Formal Research and Development (R\&D) spending is concentrated in OECD countries and developing countries spend relatively less on basic science and innovations. Therefore, they rely even more on the international diffusion of technology. Recent research (Eaton and Kortum (1999)) concluded that international technology transfers are the major sources of technical progress for both developed and developing countries. Keller (2004) argues that technology comes more from abroad (90 percent or more) than from inside the country. The important question is: is human capital also important for international technology adoption and diffusion? Empirical and theoretical papers suggest the affirmative. Xu (2000) show that inward technology diffusion increases with a country's human capital. Other major determinants of international technology diffusion are Research and Development expenditures, trade through intermediate input imports, learning-by-exporting experience, Foreign direct investment (FDI) and communication.

Finally, education can change the structure of exports, which can become relatively more intensive and relatively less polluting increasing the capacity to implement environmental policies. If an economy grows initially with the accumulation of polluting physical capital and later with the accumulation of non-polluting human capital, then pollution can appear in the shape of a reversed U curve.

\section{Empirical analysis}

\subsection{Econometric specification}

The econometric approach of our paper is to analyze the role of education on the growth of air pollution. For this purpose, we estimate the growth of carbon dioxide emissions per capita on the level of education and a set of control variables. We write the baseline model as follows:

$$
\log \left(\frac{\theta_{i, i}}{\nabla_{i, t-1}}\right)=\beta_{1} \log \left(e_{i, t-1}\right)+\beta_{2} \log \left(h_{i, t}\right)+\delta x_{i, t}+\gamma_{t}+\alpha_{i}+\varepsilon_{i, t}
$$

with $e_{i, t}$ the average quantity of carbon dioxide per capita (in metric ton) in a country $\mathrm{i}$ in a year $\mathrm{t}, h_{i, t}$ is education, $\varepsilon_{i, z}$ is the error term, $\gamma_{t}$ is time effect, $\alpha_{i}$ is country specific effect and 
$x_{i, t}$ is control variables. These variables are investments, population growth rate, trade openness, political institutions and technical progress. The period ranges from 1970 to 2004 and data are compiled in five-year averages. Our sample is taken from 85 countries including 22 developed countries and 63 developing countries.

\subsection{Estimation method}

In order to estimate this model we use adequate econometric techniques. The panel data take into account transversal and temporal dimensions and the unobserved heterogeneity (for example influence of economic specificities and environmental policies, etc.). We can run estimations using OLS (Ordinary Least Square). However, OLS estimator is weak and biased because our model is a dynamic panel and dependent variable is lagged and endogenous. We then take into account country and time fixed effects and use the GMM (Generalized Method of Moment) System. The first-differenced generalized method of moments estimators applied to panel data models addresses the problem of the potential endogeneity of some explanatory variables, measurement errors and omitted variables. The idea of the first-differenced GMM is "to take first differences to remove unobserved time invariant country specific effects, and then instrument the right-hand-side variables in the first-differenced equations using levels of the series lagged one period or more, under the assumption that the timevarying disturbances in the original levels equations are not serially correlated" (Bond, Hoeffler and Temple 2001). The GMM System estimator combines the previous set of equations in first differences with suitable lagged levels as instruments, with an additional set of equations in levels with suitably lagged first differences as instruments. Blundell and Bond (1998) provide evidence with Monte Carlo simulations that GMM System performs better than first-differenced GMM, the latter being seriously biased in small samples when the instruments are weak. To test the validity of the lagged variables as instruments, we use the standard Hansen test of overidentifying restrictions, where the null hypothesis is that the instrumental variables are not correlated with the residual, and the serial correlation test, where the null hypothesis is that the errors exhibit no second-order serial correlation. In our regressions, none of the tests on the statistics allows us to reject the validity of the lagged variables as instruments as well as the lack of second order autocorrelation.

\subsection{Descriptive analysis of data}

The data on carbon dioxide emissions per capita, the investment rate, the trade openness and the population growth rate are from the World Development Indicators (World Bank, 2005). The data on education and political institutions come respectively from Barro and Lee (2000) and Polity IV (2002). 
The emissions of carbon dioxide per capita are measured in metric ton per capita and are estimated from the combustion of fossil energies and cement industries in the liquid, solid or gas form. Trade openness and investment respectively correspond to the share of the sum of exports and imports and investments in gross domestic product (GDP). As political institutions variable, we chose the index of polity(2), which is a score obtained by differenciating the index of democracy and the index of autocracy on a scale going from +10 (democracy) to -10 (autocracy). The indicator of democracy is characterized by the effective existence of institutional rules framing of the power and the presence of institutions enabling citizens to express their expectations and to choose political elites. Autocracy is characterized by the absence or the restriction of political competition, economic planning and control. The exercise of power is slightly constrained by institutions and the leaders are only selected within a "political elite". The data on education resulting from Barro and Lee (2000) correspond to the average schooling years in the total population.

Table (1) presents descriptive statistics of education, carbon dioxide emissions level and growth rate. It shows a high growth rate of carbon dioxide emissions per capita in the world (8.23\%). This can be explained by the pollution growth rate in developing countries $(9,4 \%)$ indicating their importance in the pollution phenomenon, contrary to developed countries $(4,3 \%)$. We also noticed that countries (Developed countries) with high carbon dioxide emissions are relatively more educated and have low carbon dioxide growth rate.

Table 1: Descriptive statistics of emissions of dioxide carbon and education

\begin{tabular}{lcccc}
\hline \hline & Average & Standard deviation & Min & Max \\
\hline World & & & & \\
Growth of emissions per capita & 0,08 & 0,35 & $-4,44$ & 2,76 \\
Emissions per capita & 4,56 & 7,91 & 0,001 & 78,61 \\
Education & 4,67 & 2,06 & 0,042 & 12,21 \\
\hline Developed countries & & & $-1,03$ & 2,76 \\
Growth of emissions per capita & 0,04 & 0,29 & 1,72 & 78,61 \\
Emissions per capita & 12,26 & 12,11 & 2,44 & 12,21 \\
Education & 7,93 & 2,05 & & \\
\hline Developing countries. & & & $-4,44$ & 2,59 \\
Growth of emissions per capita & 0,09 & 0,37 & 0,001 & 29,10 \\
Emissions per capita & 2,17 & 3,55 & 0,04 & 10,27 \\
Education & 3,41 & 2,19 & & \\
\hline \hline
\end{tabular}

Notes: the total sample is composed of developed and developing countries over the period 1970 -2004

Source: Author 


\subsection{Results}

Table (2) presents results obtained by the Generalized Method of Moments-system (GMM-system). Column (1) shows the absence of conditional convergence in carbon dioxide emissions per capita in the world because the coefficient is insignificant and equals

- 0.003. This result conforms to previous studies (Westerlund and Basher (2008), Aldy (2006)) concluding on the absence of a convergence in air pollution at the international level. Investment, which is the driving force behind economic growth and economic development, contributes at great length to pollution growth. Technical progress has a negative and significant effect on pollution growth, whereas education and political institutions have no impact on it.

Since countries develop pollution behaviours according to their economic development, we separate developing countries from developed countries. Indeed, we can suppose that Botswana and Luxemburg could have different pollution behaviors.

Columns 2 and 3 of the table (3) show the results when the sample is restricted to developing countries or developed countries. We find a conditional convergence in carbon dioxide emissions per capita for developed countries and a divergence for developing countries. We also note that the effects of education and political institutions on pollution growth are significantly different according to the level of development (developing or developed countries). Indeed, education favours pollution growth in developed countries, contrary to developing countries. We get the same result for political institutions, which contribute respectively to pollution (depollution) in developing (developed) countries.

The role of institutions and human capital as fundamental sources of difference in economic development, highlighted by the economic literature, questions us about the possibility that the effect of education on the environment could differ according to the quality of institutions in a given country. 
Table 2: Effect on education on the growth of carbon dioxide per capita (GMM-System)

\begin{tabular}{|c|c|c|c|c|c|}
\hline & \multirow[t]{2}{*}{ All countries (1) } & \multirow{2}{*}{$\begin{array}{c}\text { Developing countries } \\
\text { (2) }\end{array}$} & \multicolumn{3}{|c|}{ Developing countries } \\
\hline & & & (3) & (4) & (5) \\
\hline Log of initial carbon & -0.003 & 0.008 & $-0,305$ & -0.009 & $-0,201$ \\
\hline dioxide per capita & $(-0.18)$ & $(0.05)$ & $(-2,17)^{* *}$ & $(-0.72)$ & $(-2,14)^{* *}$ \\
\hline \multirow[t]{2}{*}{ Log of investment } & 0.326 & 0.315 & 0.549 & 0.401 & 0.337 \\
\hline & $(2.50)^{* *}$ & $(2.40)^{* *}$ & $(3.19)^{* *}$ & $(3.29) * *$ & $(2.85)^{* *}$ \\
\hline \multirow[t]{2}{*}{ Log of trade openness } & 0.086 & 0.203 & 0.027 & 0.151 & 0.017 \\
\hline & $(0.93)$ & $(1.51)$ & $(0.48)$ & $(1.32)$ & $(0.43)$ \\
\hline Democratic & 0.036 & 0.043 & -0.049 & 0.034 & -0.035 \\
\hline Institutions & $(1.73)$ & $(2.07)^{* *}$ & $(10.56)^{* * *}$ & $(1.75)^{* *}$ & $(1.36)$ \\
\hline \multirow[t]{2}{*}{ Growth of population } & $-0,034$ & $-0,160$ & $-0,104$ & $-0,15$ & $-0,026$ \\
\hline & $(0,30)$ & $(1,43)$ & $(2,47)^{* *}$ & $(1,37)$ & $(1,84)^{* *}$ \\
\hline \multirow[t]{2}{*}{ Education } & 0.253 & -0.219 & 0.445 & -0.047 & 0.545 \\
\hline & $(0.83)$ & $(0.96)$ & $(3.76)^{* * *}$ & $(0.27)$ & $(12.45)^{* * *}$ \\
\hline Education* & & & & $-0,008$ & $-0,035$ \\
\hline Democratic & & & & $(0,94)$ & $(2,91)^{* * *}$ \\
\hline \multicolumn{6}{|l|}{ Institutions } \\
\hline \multirow[t]{2}{*}{ Constant } & -1.293 & -1.329 & -0.294 & -1.562 & -1.269 \\
\hline & $(1.84)^{*}$ & $(1.90)^{*}$ & $(1.91)^{*}$ & $(2.32)^{*}$ & $(2.51)^{* *}$ \\
\hline$\overline{\text { Observations }}$ & 229 & 182 & 47 & 182 & 47 \\
\hline Countries & 85 & 63 & 22 & 63 & 22 \\
\hline $\mathrm{AR}(1) / \mathrm{AR}(2)$ & $0,82 / 0,21$ & $0,57 / 0,75$ & $0,52 / 0,40$ & $0,70 / 0,36$ & $0,07 / 0,18$ \\
\hline Hansen Test $p$ value & 0,40 & 0,69 & 0,91 & 0,82 & 0,62 \\
\hline Number Instruments & 17 & 17 & 14 & 17 & 14 \\
\hline
\end{tabular}

Note: * significant at $10 \%$; ** at $5 \%$; *** at $1 \%$. The period is $1970-2004$. Temporal dummy variables have been included.

\subsubsection{The nonlinear effect of education: Interaction between education and institutions}

When considered a public good, the improvement of the quality of the environment could not be directly determined by people's preference but rather by their reflection through political institutions. In other words, the interaction between education and political institutions could affect environmental protection. Mahon (2006) considers that the effect of education on the quality of the environment could be more effective in the presence of stable political institutions that are considered a channel of expression for the people. Including an interactive variable between education and institutions in our equation suggests that the effect of education on pollution growth would be conditional on political institutions. 
Columns (4) and (5) confirm that the growth rate of carbon dioxide per capita positively and significantly depends on the investment rate. This variable is an important determinant of air pollution in developing countries. In these countries, people are not very concerned with environment problems. They are worried by many development problems (low and unstable growth, unemployement). These investments can also reduce poverty because they are a driving force of economic growth. Foreign and domestic investments allow countries to access international markets, trade, new technologies and competences. However, these opportunities can differ with the development of countries.

In some countries, investments are directed towards the building, services and manufacturing sectors. In other countries, they are directed towards the natural resource sectors, in particular oil firms and wood companies, which are big energy consumers and thus pollutants. For example in Africa, $65 \%$ of direct foreign investments go to the natural resources sector. The expected effects are a rise in employment, a rise in taxes, a rise in state revenues and the reduction of poverty. These countries can also be less sensitive to environmental problems. In the same way, the weakness of infrastructures, particularly roads, strongly increases the use of energy and the consumption of polluting resources.

Political institutions have a significant and opposite effect according to the level of development. In developing countries, the positive effect can be explained by the "free rider behavior', (Carlsson and Al 2003). Political leaders consider pollution a public good and have no willingness to fight it. In developed countries, political institutions reduce carbon dioxide per capita growth. This effect is more important and significant with education. Columns (3) and (5) show that the effect of the quality of institutions on pollution growth is conditioned by the level of education.

Education seems to be a factor of air pollution in developed countries although its effect is slightly mitigated in presence of political institutions. Without political institutions, education increases pollution. Our results are similar to Jorgenson's (2003). As mentioned in the literature review, a possible explanation is that educated people have a higher income and are encouraged to overconsume. They also desire to live well by accumulating material goods without caring about the consequences of this happiness and the ideological model of “consume more to be happier" (Princen et al. 2002). Political institutions mitigate the effect of education. Although they pollute, educated people are also more conscious of environmental problems. Their education level will increase their preferences in favor of a higher level of environmental protection. They will reflect their preference through political institutions. 
In developing countries, education and its interactive variable have no effect on the growth of carbon dioxide emissions per capita. Low education level and the relative weakness of political institutions might explain the absence of effect of education in developing countries. The combination of these factors strongly reduces the ability of people to express their preferences for a better environment. Therefore, the average effect of education on emissions growth is negligible. Furthermore, less educated people (relatively to those of developed countries) are also poorer and consume less material goods, which is a factor to environmental degradation.

Technical progress has no impact on pollution growth in developed countries whereas it is the key driving force behind depollution in developing countries. These results are not surprising. In developed countries, high levels of education are also factors of knowledge, creation and technical progress. We can then think that developing countries have little technical progress and that they would need technology transfers. Since the level of technical progress is relatively low and since their technology needs are so enormous, an increase in technical progress (new technology transfers) has a high marginal effect on pollution growth. In other words, technical progress is more effective in countries that are weakly endowed with such progress.

\subsubsection{Robustness checks}

To analyse the strength of the results we consider eight other educational measures. These are: the average of schooling years in general for individuals being over 25 years old, the average of schooling years at a higher level for individuals being over 15 years old, the average of schooling years at a higher level for individuals being over 25 years old, the average of schooling years at a secondary level for individuals being over 15 years old, the average of schooling years at a secondary level for individuals being over 25 years old, the percentage of the population having completed a higher education, the percentage of the population having completed a secondary school and the percentage of the population having completed a primary school. As suggested by tables (3a) and (3b), our results remain stable inspite of the use of eight alternative variables. Thus, the average primary, secondary and high schooling years in the population have similar effects on the growth of carbon dioxide emissions per capita and these effects are different according to the level of development.

Secondly, we check if the effect of education on the growth of emissions per capita would be simply due to the omission of the income variable (GDP per capita). From the point that education contributes to a rise of income and economic growth, education increases the use of environmental resources. It is thus a source of air pollution growth through income per 
capita. Our results may also be simply explained by the omission of income (GDP/capita). That leads us to control the relevance/accuracy of our results by including income per capita. Columns 1 and 4 of table (4) show that income per capita does not have a significant effect on growth of emissions per capita. Results are stable, coherent and valid.

In recent years, the debate on climate change has been renewed because their environmental and socio-economic effects are now more evident. In response, some international agreements were signed between countries. To take into account the effect of international agreements, we include The United Nations Framework Convention on Climate Change (UNFCCC) and the Kyoto Protocol. The UNFCCC is an international environmental treaty produced at the Earth Summit in Rio de Janeiro (1992). The objective of the Treaty is to encourage a stabilization of the concentration of greenhouse gases at a level that would prevent people from dangerous anthropogenic interference with the climate system. The Kyoto protocol establishes flexible mechanisms and commitments on the part of countries to stabilize or reduce the emissions of greenhouse gases (GHGs) by 5, 3\% over the period 20082012. It will be very interesting to test the impact of the Kyoto Protocol and UNFCCC on the growth of carbon dioxide per capita. In table 4 (columns 2,3,5,6 and 7), we include "Kyoto" and "UNFCCC" variables. The dummy takes the value of one, if a country has ratified the Kyoto Protocol and faces emissions reduction obligations or the UNFCCC treaty; otherwise it takes the value zero. Our results show that the Kyoto Protocol and the UNFCCC have no impact on the growth of carbon dioxide per capita. Two arguments can explain these results. Firstly, it is very early to verify the effect of the Kyoto protocol commitments on air pollution growth because our analysis covers the period 1970-2004 and many countries only ratified it in 2002. Secondly, countries are not prompted to respect their international agreements. 
Table 3a: Effect of alternative education variables on the growth of carbon dioxide per capita (GMM-System) in developed countries

\begin{tabular}{|c|c|c|c|c|c|c|c|c|}
\hline & (1) & $(2)$ & (3) & $(4)$ & (5) & (6) & (7) & $(8)$ \\
\hline $\begin{array}{l}\text { Log of initial carbon } \\
\text { dioxide per capita }\end{array}$ & $\begin{array}{l}-0.16 \\
(-2,05)^{* * *}\end{array}$ & $\begin{array}{c}-0,15 \\
(-2,98) * * *\end{array}$ & $\begin{array}{c}-0,14 \\
(-2.89)^{* * * *}\end{array}$ & $\begin{array}{c}-0,24 \\
(-2.64)^{* * * * *}\end{array}$ & $\begin{array}{c}-0,16 \\
(-2.02)^{* *}\end{array}$ & $\begin{array}{l}-0,13 \\
(-2.71)^{* * * *}\end{array}$ & $\begin{array}{l}-0,14 \\
(-2.28)^{* *}\end{array}$ & $\begin{array}{c}-0,30 \\
(-2,30)^{* * *}\end{array}$ \\
\hline Educ1 & $\begin{array}{c}0.539 \\
(12.52)^{* * * *} \\
-0.040\end{array}$ & & & & & & & \\
\hline PolityEduc1 & $(3.89) * * * *$ & & & & & & & \\
\hline Educ2 & & $\begin{array}{c}0.447 \\
(13.27)^{* * * *}\end{array}$ & & & & & & \\
\hline PolityEduc1 & & $\begin{array}{c}-0.038 \\
(6.68)^{* * * *}\end{array}$ & & & & & & \\
\hline Educ3 & & & $\begin{array}{c}0.439 \\
(13.62)^{* * * *}\end{array}$ & & & & & \\
\hline PolityEduc3 & & & $\begin{array}{c}-0.039 \\
(7.22)^{* * *}\end{array}$ & & & & & \\
\hline Educ4 & & & & $\begin{array}{c}0.588 \\
(10.91)^{* * *}\end{array}$ & & & & \\
\hline PolityEduc4 & & & & $\begin{array}{c}-0.039 \\
(4.37)^{* * * *}\end{array}$ & & & & \\
\hline Educ5 & & & & & $\begin{array}{c}0.487 \\
(10.46) * * * *\end{array}$ & & & \\
\hline PolityEduc5 & & & & & $\begin{array}{c}-0.044 \\
(10.02) * * *\end{array}$ & & & \\
\hline Educ6 & & & & & & $\begin{array}{c}0.442 \\
(11.70) * * *\end{array}$ & & \\
\hline PolityEduc6 & & & & & & $\begin{array}{l}-0.038 \\
(8.53)^{* * * *}\end{array}$ & & \\
\hline Educ7 & & & & & & & $\begin{array}{c}0.522 \\
(9.76) * * *\end{array}$ & \\
\hline PolityEduc7 & & & & & & & $\begin{array}{l}-0.048 \\
(11.79) * * * *\end{array}$ & \\
\hline Educ8 & & & & & & & & $\begin{array}{c}0.551 \\
(10.49)^{* * *}\end{array}$ \\
\hline PolityEduc8 & & & & & & & & $\begin{array}{c}-0.043 \\
(8.72)^{* * *}\end{array}$ \\
\hline Number of countries & 22 & 22 & 22 & 22 & 22 & 22 & 22 & 22 \\
\hline
\end{tabular}


CERDI, Etudes et Documents, 2010.28

Table 3b: Effect of alternative education variables on the growth of carbon dioxide per capita (GMM-System) in developing countries

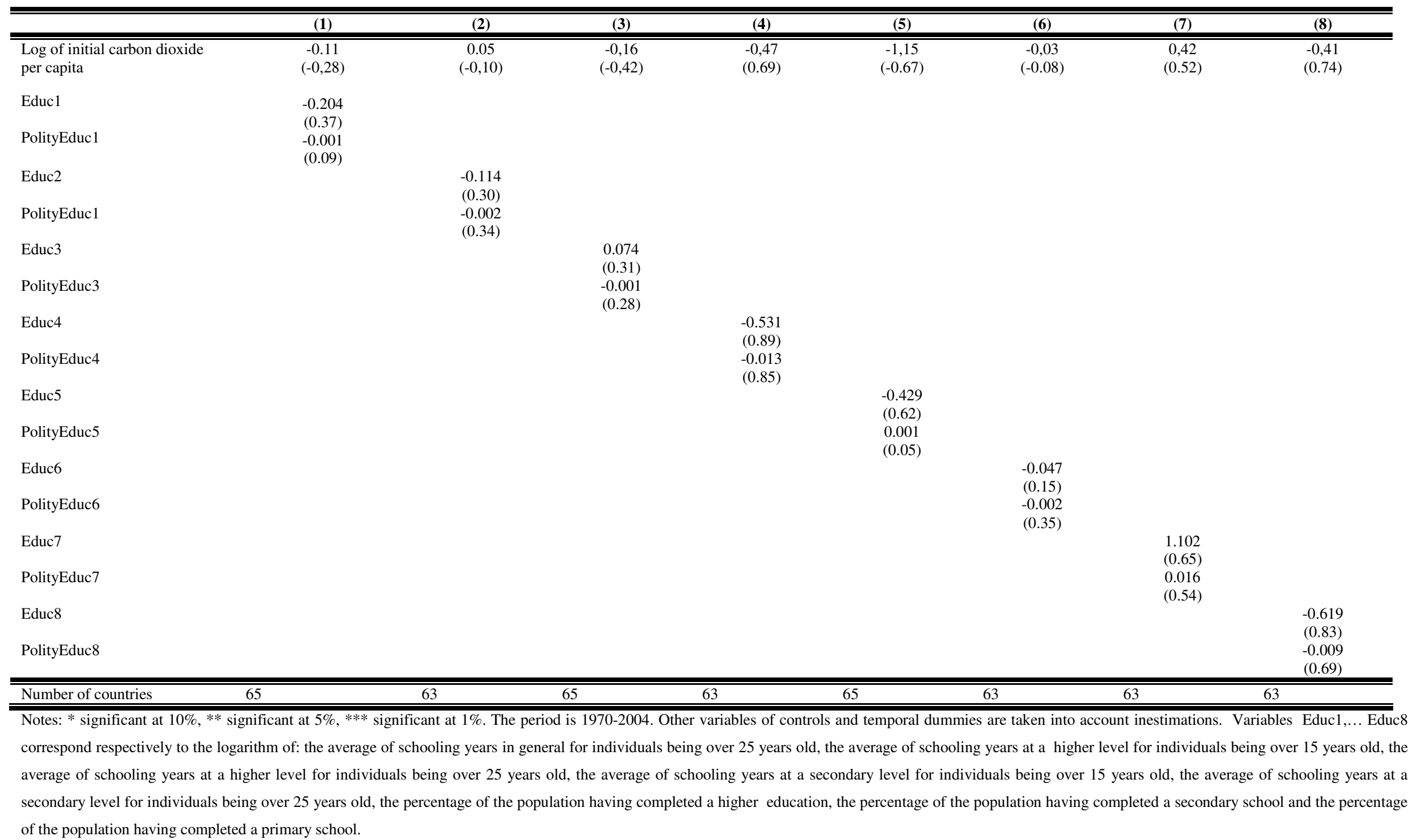


Table 4: Effect of education on the growth of carbon dioxide per capita including international agreements and income

\begin{tabular}{|c|c|c|c|c|c|c|c|}
\hline \multirow{2}{*}{$\begin{array}{l}\text { Growth of carbon } \\
\text { dioxide Capita } \\
\text { (GMM-system) }\end{array}$} & \multirow[b]{2}{*}{ (1) } & \multicolumn{2}{|c|}{ Developed countries } & \multicolumn{3}{|c|}{ "Developing countries } & \multirow[b]{2}{*}{ (7) } \\
\hline & & (2) & (3) & (4) & $(5)$ & (6) & \\
\hline $\begin{array}{l}\text { Log of initial carbon } \\
\text { dioxide per capita }\end{array}$ & $\begin{array}{c}-0,19 \\
(-2,14)^{* *}\end{array}$ & $\begin{array}{l}0.19 \\
(3.16) * * *\end{array}$ & $\begin{array}{l}0.19 \\
(2.92)^{* * * *}\end{array}$ & $\begin{array}{l}-0,084 \\
(-0,61)\end{array}$ & $\begin{array}{l}0.11 \\
(0,99)\end{array}$ & $\begin{array}{l}0.19 \\
(1.30)\end{array}$ & $\begin{array}{l}0.15 \\
(0.52)\end{array}$ \\
\hline Log of Investment & $\begin{array}{c}0.340 \\
(2,80)^{* *}\end{array}$ & $\begin{array}{l}0.330 \\
(1.39)^{* * *}\end{array}$ & $\begin{array}{l}0.328 \\
(1.37)^{* * *}\end{array}$ & $\begin{array}{c}0.402 \\
(3.30)^{* * *}\end{array}$ & $\begin{array}{l}0.388 \\
(3.21)^{* * *}\end{array}$ & $\begin{array}{l}0.489 \\
(3.52)^{* * *}\end{array}$ & $\begin{array}{l}0.39 \\
(2.69) * * *\end{array}$ \\
\hline $\begin{array}{l}\text { Log of trade } \\
\text { openness }\end{array}$ & $\begin{array}{l}0.026 \\
(0.51)\end{array}$ & $\begin{array}{l}0.025 \\
(0.46)\end{array}$ & $\begin{array}{l}0.024 \\
(0.43)\end{array}$ & $\begin{array}{l}0.147 \\
(1.30)\end{array}$ & $\begin{array}{l}0.068 \\
(0.50)\end{array}$ & $\begin{array}{l}0.044 \\
(0.36)\end{array}$ & $\begin{array}{l}0,013 \\
(0.11)\end{array}$ \\
\hline Technical progress & $\begin{array}{l}0.031 \\
(1.04)\end{array}$ & $\begin{array}{l}0.046 \\
(0.43)\end{array}$ & $\begin{array}{l}0.047 \\
(0.70)\end{array}$ & $\begin{array}{c}-0.178 \\
(2.16)^{* *}\end{array}$ & $\begin{array}{l}-0.104 \\
(2.01)^{* *}\end{array}$ & $\begin{array}{l}-0.091 \\
(1.71)^{*}\end{array}$ & $\begin{array}{l}-0.04 \\
(1.85)^{*}\end{array}$ \\
\hline Political institutions & $\begin{array}{l}0.035 \\
(1.45)\end{array}$ & $\begin{array}{l}0.943 \\
(0.22)\end{array}$ & $\begin{array}{l}0.717 \\
(0.12)\end{array}$ & $\begin{array}{c}0.034 \\
(1.76)^{*}\end{array}$ & $\begin{array}{l}0.036 \\
(1.89)^{*}\end{array}$ & $\begin{array}{l}0.033 \\
(2.24)^{* *}\end{array}$ & $\begin{array}{l}0.043 \\
(2.24) * *\end{array}$ \\
\hline Population rate & $\begin{array}{l}-0.029 \\
(1.69)\end{array}$ & $\begin{array}{l}-0.093 \\
(1.69)\end{array}$ & $\begin{array}{l}-0.096 \\
(1.66)\end{array}$ & $\begin{array}{l}-0.140 \\
(1.27)\end{array}$ & $\begin{array}{l}-0.100 \\
(0.81)\end{array}$ & $\begin{array}{l}-0.075 \\
(0.69)\end{array}$ & $\begin{array}{l}0.004 \\
(0.13)\end{array}$ \\
\hline Education & $\begin{array}{c}0.542 \\
(12.63)^{* * *}\end{array}$ & $\begin{array}{l}18.015 \\
(2.32)^{* * *}\end{array}$ & $\begin{array}{l}13.918 \\
(2.25)^{* *}\end{array}$ & $\begin{array}{l}0.005 \\
(0.02)\end{array}$ & $\begin{array}{l}0.084 \\
(0.56)\end{array}$ & $\begin{array}{l}0.212 \\
(1.07)\end{array}$ & $\begin{array}{l}-0.008 \\
(0.04)\end{array}$ \\
\hline $\begin{array}{l}\text { Education* Political } \\
\text { Institutions }\end{array}$ & $\begin{array}{c}-0.036 \\
(3.14) * * *\end{array}$ & $\begin{array}{l}-1.787 \\
(2.32)^{* *}\end{array}$ & $\begin{array}{l}-1.377 \\
(2.24)^{* *}\end{array}$ & $\begin{array}{r}-0.009 \\
(0.95)\end{array}$ & $\begin{array}{l}-0.010 \\
(0.90)\end{array}$ & $\begin{array}{l}-0.004 \\
(0.49)\end{array}$ & $\begin{array}{l}-0.02 \\
(1.04)\end{array}$ \\
\hline $\begin{array}{l}\text { Log of income per } \\
\text { capita }\end{array}$ & $\begin{array}{l}0.006 \\
(0.42)\end{array}$ & & & $\begin{array}{l}0.004 \\
(0.33)\end{array}$ & & & \\
\hline UNFCCC & & $\begin{array}{l}0.090 \\
(1.54)\end{array}$ & & & $\begin{array}{l}-0.018 \\
(0.06)\end{array}$ & & \\
\hline Kyoto & & & $\begin{array}{l}0.081 \\
(1.14)\end{array}$ & & & $\begin{array}{l}-0.134 \\
(1.15)\end{array}$ & \\
\hline CDM & & & & & & & $\begin{array}{l}0.21 \\
(1.19)\end{array}$ \\
\hline Constant & $\begin{array}{c}-1.407 \\
(2.55)^{* *}\end{array}$ & $\begin{array}{l}-10.193 \\
(2.25)^{* *}\end{array}$ & $\begin{array}{l}-7.913 \\
(2.16)^{* *}\end{array}$ & $\begin{array}{l}-1.61 \\
(2.46)^{* *}\end{array}$ & $\begin{array}{l}-0.877 \\
(1.84)^{*}\end{array}$ & $\begin{array}{l}-1.232 \\
(2.27)^{* *}\end{array}$ & $\begin{array}{l}1.48 \\
(2.17)^{*}\end{array}$ \\
\hline Observations & 47 & 47 & 47 & 161 & 170 & 170 & 170 \\
\hline Number of countries & 22 & 22 & 22 & 63 & 63 & 63 & 63 \\
\hline $\mathrm{AR}(1)$ & 0.22 & 0,071 & 0,06 & 0.51 & 0,32 & 0,35 & 0.52 \\
\hline $\operatorname{AR}(2)$ & 0.72 & 0,24 & 0,17 & 0.81 & 0,45 & 0,47 & 0.40 \\
\hline Hansen Test & 0.83 & 0,75 & 0,69 & 0.72 & 0,72 & 0,48 & 0.90 \\
\hline Number Instruments & 14 & 15 & 15 & 17 & 27 & 27 & 27 \\
\hline
\end{tabular}

Notes: * significant at 10\%, ** significant at 5\%,*** significant at 1\%. The period is 1970-2004. Temporal dummies are taken into account. 


\section{Conclusion}

This study brings to light the effect of education on the growth of air pollution over the period 1970-2004 in 85 countries. Our results suggest that education has no impact on the growth of air pollution for the whole sample. Nonetheless, this effect is sensitive to the sampling of countries according to their level of development. Indeed, while the effect remains insignificant in the developing countries sub-sample, education does matter for air pollution growth in the developed countries. More interestingly, when controlling for the quality of political institutions, the positive effect of education on air pollution growth is mitigated in the developed countries while being insignificant in the developing countries.

Our results also show a divergence in carbon dioxide per capita at a global level during the period 1970-2004. For developing countries, there is a divergence in carbon dioxide per capita. Technical progress contributes to a reduction in air pollution growth. Investment, which is the driving force behind economic growth, is an important source of pollution in both developing countries and developed countries. For the latter, air pollution per capita converges. The carbon dioxide emissions convergence in developed countries and divergence in developing countries highlight the interests and difficulties of multilateral negotiations on global warming. The article also highlights the importance of other factors such as technical progress, political institutions and investments in pollution growth.

Our results are important for economic policies. Initially, they highlight the importance of education in environmental protection. The current accumulation of knowledge is a factor of economic growth as well as of pollution growth. We are not recommending questioning educational policies, the intrinsic values of which are obvious. On the contrary, there is a need for introducing a change of perception and the role of education in favor of the environment. That should be very urgent in developing countries because the achievement of the Millennium Development Goals (MDG) regarding education will be followed by environmental pollution. Then, there is the phenomenon of the free rider in some countries, fighting against global warming. In addition, investments being a key factor of economic growth and determinant of pollution, the reduction of their effects will be necessarily followed by the setting up of ecologically appropriate investments. Finally, the divergence of pollution at an international level and at the level of developing countries requires the transformation of the Kyoto protocol, which should include agreements on technology transfers and promote ecological development. 
This paper opens leads for future research. Indeed, it highlights a differentiated impact on the environment of political institutions in developed and developing countries. It will then be interesting to analyze the deep determinants of this behaviour of free riders in developing countries. 


\section{References}

Aldy, J.E. (2007) "Divergence in State-Level Per Capita Carbon Dioxide Emissions" Land Economics, 83(3), 353-369.

Bartel, A.P. and Lichtenberg, F.R.(1987) "The Comparative Advantage of Educated Workers in Implementing New Technology". The Review of Economics and Statistics, 69(1), 1-11.

Bimonte, S. (2002) "Information access, income distribution, and the Environmental Kuznets Curve" Ecological Economics, 41(1), 145-156.

Blundell, R. and Bond, S. (1998) "Initial conditions and moment restrictions in dynamic panel data models"Journal of Econometrics, 87(1), 115-143.

Bond, S.R., Hoeffler, A. and Temple, J.R. (2001) "GMM Estimation of Empirical Growth Models" CEPR Discussion Paper 3048. London, United Kingdom: Centre for Economic Policy Research.

Dasgupta, S. and Wheeler, D. (1997) "Citizen Complaints as Environmental Indicators: Evidence from China” World Bank Policy Research Working Paper No. 1704

Eaton, J. and Kortum, S. (1999) "International Technology Diffusion: Theory and Measurement” International Economic Review, 40(3), 537-570.

Farzin,Y.H. and Bond, C.A. (2006) "Democracy and environmental quality" Journal of Development Economics, 81(1), 213-235.

Grossman, G.M. and Krueger, A.B. (1995) "Economic Growth and the Environment" The Quarterly Journal of Economics, 110(2), 353-377.

Hettige, H. et al. (1996) "Determinants of pollution abatement in developing countries: Evidence from South and Southeast Asia" World Development, 24(12), 1891-1904.

Jorgenson, A.K. (2003) "Consumption and Environmental Degradation: A Cross-National Analysis of the Ecological Footprint. Social Problems, 50(3), 374-394.

Keller, W. (2004) "International Technology Diffusion” Journal of Economic Literature, 42(3), 752-782.

Nelson, R.R. and Phelps, E.S. (1966) "Investment in Humans, Technological Diffusion, and Economic Growth” The American Economic Review, 56(1/2), 69-75.

Princen, T. (2001) "Consumption and its Externalities: Where Economy Meets Ecology" Global Environmental Politics, 1(3), 11-30.

Westerlund, J. and Basher, S.A. (2008) "Testing for Convergence in Carbon Dioxide Emissions Using a Century of Panel Data” Environ Resource Econ, 40, 109-120.

$\mathrm{Xu}, \mathrm{B}$. (2000) "Multinational enterprises, technology diffusion, and host country productivity" growth. Journal of Development Economics, 62(2), 477-493. 
Wells, Louis T., Jr. (1972): “The Product Life Cycle and International Trade", In Boston: Harvard Business School Division of Research.

\section{Appendices}

\section{List of countries included in the sample}

Algeria, South Africa, Germany, Australia, Austria, Belgium, Burundi, Benin, Bangladesh, Bahrain, Bolivia, Brazil, Botswana, Canada, Central Africa, Chilie, China, Cameroun, Congo, Colombia, Costa Rica, Denmark, Dominican Republic, Ecuador, Egypt, Spain, France, Finland, Fiji, Ghana, Greece, Guatemala, Honduras, Haiti, Holland, Hungary, Indonesia, India, Iran, Israel, Italy, Jamaica, Japan, Jordan, Kenya, Luxemburg, Mexico, Mali, Mauritania, Malawi, Malaysia, New Zealand, Niger, Nicaragua, Nepal, Norway, Pakistan, Peru, Philippines, New Guinea, Guinea, Poland, Portugal, Paraguay, Rwanda, the United Kingdom, Senegal, Sri Lanka, Sierra Leone, El Salvador, Syria, Sweden, Switzerland, Togo, Thailand, Trinidad and Tobago, Tunisia, Turkey, Uganda, the USA, Uruguay, Zambia

Table5: Definition and source of variables

\begin{tabular}{|c|c|c|}
\hline Variables & Definitions & Data Source \\
\hline $\begin{array}{l}\text { Emissions of carbon dioxide } \\
\text { per capita }\end{array}$ & Carbon dioxide per capita (metric ton per capita) & \multirow{4}{*}{$\begin{array}{l}\text { World } \\
\text { Development } \\
\text { Indicators } \\
(2006)\end{array}$} \\
\hline Investment rate & Investment/PIB & \\
\hline Trade openess rate & (Exportations+Importations) / Gross Domestic Product & \\
\hline Population growth rate & Population growth rate & \\
\hline Political institutions & $\begin{array}{l}\text { Combined score of democracy and } \square \text { autocracy on a } \\
\text { scale going from }-10 \text { to } 10 \text {. (- 10) large represents a } \\
\text { big autocracy and } 10 \text {, large democracy }\end{array}$ & Polity IV \\
\hline Education & $\begin{array}{l}\text { Number of average years of instruction of the } \\
\text { population }\end{array}$ & Barrolee 2000 \\
\hline Technical progress & $\begin{array}{l}\text { Rate of technical progress, computed as the coefficient } \\
\text { of the trend }(\mathrm{t}) \text { in a regression in OLS where explained } \\
\text { variable is the intensity of economy in carbon dioxide } \\
\text { and explanatory variables are GDP per capita, trade } \\
\text { and price of energy }\end{array}$ & Author \\
\hline
\end{tabular}


Table6: Descriptive statistics

\begin{tabular}{|c|c|c|c|c|}
\hline & Average & $\begin{array}{c}\text { Standard } \\
\text { deviation }\end{array}$ & Minimum & Maximum \\
\hline $\begin{array}{c}\text { Log of initial per capita dioxide } \\
\text { carbon emissions }\end{array}$ & 4,56 & 0,35 & 0,0015 & 78,61 \\
\hline $\begin{array}{c}\text { Growth rate of dioxide carbon } \\
\text { emissions per capita }\end{array}$ & 0,08 & 7,91 & $-4,44$ & 2,76 \\
\hline Investment rate & 21,42 & 7,39 & 2,53 & 86,79 \\
\hline Trade opening rate & 71,14 & 41,51 & 5,71 & 297,33 \\
\hline Technological progress rate & $-1,46$ & 1,22 & $-7,28$ & 0,64 \\
\hline Political Institutions & 0,49 & 7,47 & -10 & +10 \\
\hline Population growth rate & 1,97 & 1,61 & $-20,36$ & 16,17 \\
\hline Education & 4,67 & 2,95 & 0,042 & 12,21 \\
\hline
\end{tabular}

Source: WDI (2006), Polity IV, Barrolee 2000 and author 